\title{
Thyroid Receptor-Interacting Protein 11
}

National Cancer Institute

\section{Source}

National Cancer Institute. Thyroid Receptor-Interacting Protein 11. NCI Thesaurus. Code C97863.

Thyroid receptor-interacting protein 11 (1979 aa, 228 kDa) is encoded by the human TRIP11 gene. This protein plays a role in ligand binding. 